\title{
建築家アントニ・ガウディと美学者パウ・ミラの諸概念の関係について
} 建築家アントニ・ガウディの建築論的言説に関する研究 (3)

\section{COMPARISON ABOUT SEVERAL CONCEPTS BETWEEN ANTONI GAUDI AND PAU MILA}

On discourse of Antoni Gaudí, (3)

\author{
山村 健 ${ }^{* 1}$, 入江正之*2
}

\section{Takeshi YAMAMURA and Masayuki IRIE}

\begin{abstract}
Antoni Gaudí based his architectural theory on several aesthetic concetps of Pau Milà y Fontanals. To figure out this relationship, we
\end{abstract} compare the discourse of A.Gaudí with that of P.Milà on the following 4 aspects.

1. Difference of the basic concept about Art, such as architecture, sculpture, and painting.

2. Comparion about Ornamentation, Creation, and Intuition.

3. About concept of "Vida" which is the core of Gaudîs architecture. And about the concept of "Síntesis".

4. How Gaudi realized the concepts of Pau Mila on his design practice,

Therefore we determine that the architectural theory of Antoni Gaudí was influenced by the aesthetic theory of Pau Milà.

Keywords :Antoni Gaudí, Manuel Milà y Fontanals, Pau Milà y Fontanals, Manuscrite de Reus, Vida アントニ・ガウディ, マヌエル・ミラ・イ・フンタナルス, パウ・ミラ・イ・フンタナルス, 日記装飾論, “生命”

\section{1. 序}

\section{1 背景}

本研究は、カタルーニャの建築家アントニ・ガウディ(1852-1926) 注 1) に関する研究の一部を成すものである。前稿、「建築家アントニ・ ガウディと美学者マヌエル・ミラの諸思想の関係についてー建築家 アントニ・ガウディの建築論的言説に関する研究(2)-」 注 2 に続くも のである。論者らは前稿において、建築家ガウディの建築論的言説 からガウディの建築観注 3) を明らかにすべく、その背景の一端にマ ヌエル・ミラの諸概念の影響があることを論じた。美学者パウ・ミ ラは拙稿注 4)において登場した美学者であり、本稿ではガウディと パウ・ミラの諸概念の関係について考察するものである。

\section{2 本研究の目的と構成}

本稿では美学者パウ・ミラと建築家ガウディの諸概念の関係を考 察し、ガウディの建築観の背景にはパウ・ミラの諸概念の影響が存 在することを明らかにする。それを本研究の目的として、前稿同様 にガウディの建築観を導く書として『日記装飾論』注5) と晚年の言葉 を用い、パウ・ミラの諸概念は彼が唯一記した美学書『直観の美学』 (1904）注6) から紐解く。

『直観の美学』の全体構成について述べる。全体は 43 の美学的概 念から構成され、総頁数 30 頁の小冊子風の体裁となっている。言 語はカタルーニヤ語である。それぞれの美学的テーマの説明が韻を
踏んだ詩的記述となっていることが本書の特徴である。例えば、「文 化」を説明する項目は次のようになっている。 CULTURA

Segons sigui la cultura

Son las arts de la hermosura

Cavant el camp es cultiva

Estudiant el gust s'aviva

この記述方法にパウ・ミラの美学観が表れている。冒頭に、「諸芸 術と詩は調和で世界を満たす」と記されており、また「芸術や詩に おいて対比が調和を生む」と述べていることから、対比によって調 和を求める考え方を確認できる。ゆえに、同書でも対比的な事例を 挙げて概念の全体像を説明する手法をとっている。例えば、「明瞭 な説明や創作は、作家のよき趣味と良識を表す。強欲と顕示欲の強 い表れは、極度の悪しき創作である。明瞭なものもしくは単純化さ れたものは、凡庸とは非なるものである」（明瞭、p. 13）というよ うに、良き例と悪しき例の二つの対比事項を並置することで概念の 全体像を述べ、次にその概念の本質的な考え方を示寸構成となって いる。さらに、二行連の詩の構造をとることで対比的な事例の並置 が明瞭になり、その上で概念の全体像と本質の関係が看破される調 和のとれた論述が特徵である。

本稿では同書を丹念に読み込み、ガウディの建築観とパウ・ミラ

\footnotetext{
*1 早稲田大学創造理工学研究科建築学科 講師・博士(建築学) Assist. Prof., Dept. of Architecture, Faculty of Sci. and Eng., Waseda University, Dr.Arch.

*2 早稲田大学 名誉教授 $\cdot$ 工博

Prof. Emeritus, Waseda University, Dr.Eng.
} 
の諸概念との関係を提示し、さらにガウディの実践においてパウ ミラから影響をうけた事例を沮上に載せることで、建築家ガウディ がパウ・ミラの諸概念に影響を受けていたことを明らかにするもの である。

なお、ガウディがサグラダ・ファミリア聖堂アトリエの自室に同 書を所蔵していたことが、弟子のジュアン・マタマラの記した記録 から判明している。同書はガウディの愛読書であったことがその記 録には書かれており、その点でも本書を研究対象とする十分な意義 があると考えている注7)

本稿は全部で五章構成である。第一章で、本研究の目的と構成を 述べる。第二章で、パウ・ミラの伝記と彼の執筆活動について整理 する。第三章で、ガウディの『日記装飾論』ならびに晚年の言葉と、 パウ・ミラの『直観の美学』に記された芸術に関する比較考察を開 始する。ガウディは建築家であり、パウ・ミラは画家であったゆえ に、両者の芸術に対する考え方の整理から出発することは妥当であ ると考える。その上で、第四章では、『直観の美学』のなかに記され た創作に関する中心的な概念である装飾、創造、直観に関する比較 考察を行い、第五章では、ガウディが実践としてパウ・ミラから影 響をうけた解剖学的視点からの創作態度を生命観の創作態度として 考察する。

\section{2. 美学者パウ・ミラに関して}

本稿で対象とするパウ・ミラに関する情報は日本語文献において 皆無である。弟のマヌエル・ミラは日本語文献でわずかに紹介され ているが、兄のものは散見されない。スペイン語、カタルーニャ語 文献を渉猟し、パウ・ミラの伝記と執筆活動に関してまとめる。

\section{1 伝記}

スペイン、カタルーニャ州にヴィラフランカ・デル・パナダスに て 1810 年 12 月 26 日に生まれる。1820 25 年には、リヨッジャ の絵画教室に通っていた。1 835 年には絵画の勉強のためにローマに 赴き、1839 年に一度バルセロナへ戻る。その後またイタリアへ渡る。 それは、1841 年の 8 月 4 日フィレンツェ付けのデッサンから確認 できる。パウ・ミラは宗教画や歴史画を専門として描いていた高名 なドイツ人画家オーバーベック注 ${ }^{8)}$ に師事した。1 844 年にバルセロ ナで開催された展覧会では、「殉教者聖エウラリア」(原題: Martiro de Santa Eulalia)、「天使」(El Angel)、「聖母マリアと幼子イエス、捕ら われの聖フアン」(La virgen con el niño Jesus y la prisión de San Juan) などの作品を展示した。1 850 年には、ミラ自身が「アラゴンのペド ロ III 世とテンプル騎士団教育をうけたハイメI 世からコラディー ノの手袋を受け取るシチリア人」(Los sicilianos presentando el guente de Coradino a D. Pedro III de Aragón y D.Jaime I recibiendo la educación de los templarios) を発表した。1859 年にはバルセロナ司教から自邸 の礼拝堂のために、「受胎告知」の絵画の制作依頼を受けている。そ の後パウ・ミラはまたバルセロナに戻り、1851年 2 月 24 日に絵画 とデッサンを教えるため、芸術史及び芸術理論の教授として教鞭を 執り始めた。所属は、バルセロナの美術アカデミー上級研究員であ った。1856 年その職を辞任した。新聞ではこのことが取り上げられ、 パウ・ミラの決断は多くの教え子に衝撃を与えた。その後は、バル セロナ市内で美学に関する勉強会を不定期に開催していた。1 862 年、 カタルーニャのアテネオにて手工芸職人のための装飾について、
1868 年には、キリスト教芸術と融合したゴシック建築の卓越性につ いて、1872 年にはアテネオ・バルセロネスにおいて、ギリシア時代 の造形芸術に関する考察についてなど多数の講演も精力的に展開し ていた。1 847 年には「エル・レナシミエント」と題された美術新聞 へ寄稿した。退任時の 1858 年 1 月 25 日には弟子たち編纂したパ ウ・ミラの絵画の作品集も作成されている。弟子には近代カタルー ニャの画家として大成するマリアーノ・フルトゥニー注9) の名前もあ る。生涯美術界との関係は強く、州立美術アカデミー、カタルーニ ヤ州立歴史的遺構委員会会員で、1866 年にはアテネオ・カタラン代 表にもなっている。1 883 年 1 月 16 日に他界。彼の遺体は、生まれ 故郷へと移され、弟マヌエル・ミラの横で眠っている。

\section{2 パウ・ミラの執筆活動に関して}

本研究の対象である『直観の美学』に関して述べる。バルセロナ 文学界が出版している『19 世紀カタルーニャの芸術家ならびに文学 者の伝記および書誌』注 ${ }^{10)}$ によれば、同書は「建築史に関するノー ト」（第二巻、p.184）と記されており当時は建築書として認識され ていたことが確認できる。同書は三版あり、一版はセレスティーノ・ ヴァルダゲー出版社注 11)、二版はレミレス・イ・カルロス出版社か ら乼 12)、共に 1878 年に出版されている。もともとは、カタルーニャ 州アル・ヴァンドレイ市より出版された雑誌アル・ヴァンドレイエ ンセ注 13) の 298-301 号に揭載されたものであり、それらを編纂した ものである。時期としては、同雑誌に 1898 年の 6 月 12 日から 7 月 3 日まで隔週に渡って掲載された。これはガウディの生前に発表さ れた論考であり、その点が重要である。またその後、1904 年に友人 のホセ・ジョヴァリョールの薦めで再版されており、本研究ではま とめられた書籍を対象とする注 14 )。

この他には、『スペイン絵画概論』に記された短い論考もある。パ ウ・ミラが宗教絵画に関して付した注は興味深い注 ${ }^{15)}$ が、今回の考 察の趣旨とは異なるため、本稿の研究対象とはしていない。

\section{3.芸術に関する比較考察}

本章では、ガウディとパウ・ミラの芸術に関する比較考察を行う。 まず、両者の芸術に関する考え方を明らかにし、次に建築、彫刻、 絵画の視覚芸術に関して比較考察を進めていく。

\section{1. 建築、彫刻、絵画、音楽、詩作の位置づけ}

ガウディは晚年の言葉において芸術の定義を述べる。「建築とは、 第一の造形芸術である。彫刻や絵画は建築を必要とする。建築の卓 越性は寸べて光から生じる。建築は光の秩序である。それに対して、 彫刻は光の戯れであり、絵画は色彩による光の再現である。色彩は 光の分解である」注 16$)$ と述べている。前稿において考察した美学者 マヌエル・ミラが挙げるように芸術には音楽や詩作も含まれるのが 一般的である。しかし、それとは異なりガウディは視覚芸術を芸術 の主要素として捉えている。それは、「視覚は栄光の感覚であり(な ぜならば、栄光は表現豊かな造形である)、聴覚は信仰の感覚である」注 17) と、視覚芸術を光に関する芸術と捉えていたからである。

次にパウ・ミラの芸術の概念をみてみる。パウ・ミラは、芸術は 五つの要素で構成されているという。「美しき芸術においては、第一 に建築があり、第二に彫刻があり、第三に絵画があり、第四に調和 の芸術があり、最後に詩作がくる」(p.24) と述べている。第四の「調 和の芸術」とは、その後の記述から音楽であることが明記されてい 
る。パウ・ミラは音楽や詩作を含めた聴覚芸術も扱っている。パウ・ ミラのこの芸術の定義は、マヌエル・ミラのそれと同じである。ま た、音楽を「調和の芸術」と呼んでいる点も同様である。

ガウディは建築、彫刻、絵画を主たる芸術としていたのに対し、 パウ・ミラは建築、彫刻、絵画、音楽、詩作としている。本章では、 両者に共通する建築、彫刻、絵画を対象として考察を進める注 ${ }^{18)}$ 。

\section{2. 建築に関して}

パウ・ミラの建築についての概念を見てみる。

「美と構築の統合は、建築的芸術である。ギリシア聖堂の様式 は、高貴で明快である。ローマ時代の建築は、優雅さの結晶であ る。ゴシック建築は、最も精神的である。ムデハル様式だけが、 スペインのものであるといえよう。アルベルトゥス・マグヌス は八角形のシステムを考慮した時に、頂点を極めた。ジョット は司祭でありながら、建築家であり、画家であった。アルベルテ イとブルネッレスキは、ロマネスク芸術とキリスト教芸術の統 合を試みた。ブォナロッティ(ミケランジェロ) は、四芸術を制 覇した男である。ルネッサンスは隆興の意味である」（p.24）。 上記の記述からパウ・ミラの建築の定義が「美と構築」の統合で あることが確認できる。パウ・ミラはローマ留学時にラファエロ前 派一影響を与えたナザレ派を信奉した芸術家と親交を深めた。彼ら は中世やジョットらを含む初期イタリア・ルネッサンス芸術を範と していた。その影響によりルネッサンス建築が一つの理想となって いることも確認できる。

ここで、ガウディの記述や晚年の言葉において、登場する建築家 をみてみよう。『日記装飾論』においては、ヴィオレ・ル・デュック の名前が筆頭に出てくる。当時の建築家ならびに建築学生は、ヴィ オレ・ル・デュックの『建築辞典』に特別な信頼を寄せていた。 $\mathrm{O}$ ・ ブイガスはヴィオレの影響が「これほど広範にしっかり根付いた地 域は他にはないだろうし、このことはとりわけ、純粋なゴシック〈復 興〉以上に合理的主義的態度の数々に当てはまる」注 ${ }^{19)}$ と記述して いる。それにも関わらず、パウ・ミラは一切、ヴィオレに関する記 述は記していない。その理由としては、ヴィオレ・ル・デュックは 実作が少なく、むしろ理論家であったからではないかと考えられる。 しかし、その理論もガウディが述べる通り注 20)、理論家としては「不 完全」であり、建築家としても「美と構築」の統合である建築をつ くっていないために、パウ・ミラの評価には入らなかったのだろう と考えることができる。

他にもガウディは、イタリア・ルネッサンスの建築家を除くと、 ウィトルウィウスやガルニエ、コルビュジェについては語っている が、パウ・ミラの書物には記されていない。

ガウディが語ったイタリア・ルネッサンスの芸術家は、チェルリ ーニ、サンソヴィーノらなどであった。その中でもミケランジェロ に関する言説は注目に值する。

「ルネサンスの建築家たちのほとんど全てが彫刻家であり、した がって、厳密には装飾家たち(ミケランジェロ、サンソヴィー） など）であった。ローマのサン・ピエトロやシスティーナは装飾 家の仕事であって建築家のものではない。その意味では、構想 したブラマンテは最高の建築家であった」注21)。

この一文から、ガウディはミケランジェロよりもブラマンテを評 価していたことが確認できる。ガウディはサン・ピエトロ寺院にお
いて、ブラマンテからミケランジェロへと計画が変更になった建設 過程を自身のサグラダ・ファミリアと重㸚合わせて発言している。 ブラマンテが構想したギリシア十字の平面図を「反故」にしてラテ ン十字の平面図へと変更したのがミケランジェロであり、「計画をす るものは、後継者にたいして極めて重要な主導権を握っている」 （MM.1914-02）と述べ、初期の計画の重要性を強く訴えている。 これはガウディ自身がヴィリャールから引き継いだサグラダ・ファ ミリア聖堂建設の困難を吐露した言葉である。自分の経験を重ねる ことでブラマンテの偉大さを捉えていたと考えられる。また、ミケ ランジェロを彫刻家として捉えている発言からは、初期の計画案を そのまま引き継いだ場合の芸術家は、建設過程で付加的に装飾を足 していくため、独創的な創作とは呼べない。ゆえに建築家ではなく 装飾家であると指摘していると換言できる。

ここで両者の比較をしてみると、パウ・ミラが「建築は美と構築 の統合」であると述べるのに対して、ガウディは建築の定義に一文 で断言するような言説は残していない。「何よりも重要なことはもの とものとの関係、つまり配置することである」（Bg.CGB-030）と語 った言葉があるが、物質的で具体的な関係性を重要視した内容であ る。これはパウ・ミラの抽象的な内容とは異なるものである。ガウ ディはパウ・ミラよりむしろ原理的な建築論を教示したマヌエル・ ミラから深い影響を受けたと考えられる。その一端として、ウィト ルウィウスに関する言説において、建築論の核となる比例原理の問 題に関して指摘していることが挙げられるであろう。

次にガウディとパウ・ミラが引用した建築家たちを比較してみる と、その多くにおいて一致していない。唯一共通するのがミケラン ジェロである。しかし、パウ・ミラはミケランジェロを建築家の頂 点のように位置づけているのに対して、ガウディは建築家ですらな く、装飾家として位置づけているのは興味深い違いである。

\section{3. 彫刻に関して}

まず、彫刻に関するガウディの理解についてみる。彫刻は建築に 付されるものであると『日記装飾論』に記されている注22)。また、彫 刻が建築をより豊かにするものでありながらも、その独立性が求め られると述べる。「彫刻的装飾は表面に重苦しさを与えることなく、 常にその重要性を増することを目的としている」（原本 12 頁）その 際には彫刻が建築から独立して浮かび上がってくるようにしなけれ ばならないとして、彫刻自体の存在も「彫刻が建物と一体であると き以外は、その彫刻が良く見える場所に配置しなければならない。 そうでないと、全体として彫刻の輪郭が浮き立たない。もし、彫刻 の輪郭・シルエットを求めて配置しないのであれば、置くべきでは ない」（原本 48 頁）として、彫刻の置き方に関して指摘している。

他にも、ガウディが彫刻家として認識していたのは、フィディア ス注23)とリュシッポスであった。

「それらの神秘とは、兆しは知覚できないような繊細さであり、 その中で部分的には同一でない大きさやプロポーションの法則 や視覚的な効果が解決されているのだ。このことは、自然の中 に発見されることであり、芸術では、完全な作品にだけみられ る。彫刻では、フィディアスは偉大であり、リュシッポスも同様 で、人体の美しさとプロポーションの感覚を持っている」注 24)

ここでガウディが古代ギリシア芸術を賞賛していたことが確認で きる。『日記装飾論』において、ガウディはギリシアの彫刻を「それ 
自身完全に独立した申し分のない対象物の構成」(原本 54 頁)を備え ており、フィディアスが造ったパルテノンの彫刻は「建築を損なう 輪郭ではなく、建築を価值付け、建築を損なうことなくそれに順応 する輪郭を創造し、描き出す」(原本 50 頁) 正確な観念を与える彫刻 であると賞賛している。

次にパウ・ミラの彫刻の定義をみてみよう。

「美しき人体は、彫刻の炎である。絵画はダイアローグであり、 彫刻はモノローグである。ギリシア彫刻に関しては、フィディ アスが最も評価される人物である。ピサツのような繊細で神々 しいレリーフを作った彫刻家は他にはいない。ドナテッロの彫 刻は、一流の巨匠の証である。ギベルティは、芸術と科学を統合 して、フィレンツェの扉を造った。彫刻家ミケランジェロは弟 子を残さなかった」(彫刻、p. 25)。

パウ・ミラは「美しい人体」を創造する彫刻家を評価している。 その基準に該当する彫刻家はギリシア時代とイタリア・ルネッサン ス時代の彫刻家である。ギリシア時代の彫刻家としては、フィディ アスを高く評価している。先ほど示したように、ガウディのフィデ イアスへの評価は、彼がもっていた「プロポーション感覚」であっ たのに対し、パウ・ミラも「美しき人体」と述べており、同じ概念 である。ガウディはサグラダ・ファミリア聖堂において様々な彫像 を制作した。その制作過程において膨大なエスキスを重㸚る。特に、 人体像の見え方に関しては多大なエネルギーを投入した。パウ・ミ ラが理想とした彫刻家たちの共通点は、人体像を丹念に研究した彫 刻家であるという点である。ギリシア時代の彫刻家ならびにドナテ ッロは、ギリシア時代の人体彫刻を研究して名声を得たイタリア・ ルネッサンスを代表する彫刻家である。この人体像のプロポーショ ンや美しさを追求する彫刻の美学は、ガウディの晚年の創作方法一 と繋がるものである。それに関しては第五章で詳述する。

\section{4. 絵画に関して}

ガウディは絵画に関して、光との関係と、距離によって色彩の考 え方が異なることを次のように指摘している。

「距離を置いた光であればあるほど望ましく、壁画により多く の利益をもたらすことができ」注 25)、「透明性と華麗さを備えよ うする絵画は、遠くに置かれるなら輪郭はクッキリと描かれな ければならず、中間色や色のぼかしは故意に作られた色よりも、 色彩同士の干渉で作られるのがよい。距離が近づくなら、自然 の模倣がより際立つのである」(原本 62 頁)

ガウディは絵画に関して様々な画家の名前を列挙する。その中に は、ベンヴェヌート・チェッリーニや、ラファエロ・サンティなど、 イタリア・ルネッサンスの画家の名前が数多く登場する。

また、ガウディは晚年の言葉において次のように述べている。

「苦痛は生命の小さな苦しみに真の価值を与え、風が乾いた木 の葉を運び去るように、取るに足りぬ細心さを消失させる。こ

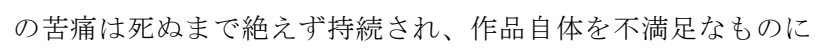
する。(これは作品に満足すると身を引いてしまう。それゆえ、 偉大な先達だけが苦痛の努力を続けることができる。）しかし、 この魂の破砕の中に貴重な断片、後の世代を堪能させる味わい と香りが残るのである」注 26)

絵画制作をこえて、創作活動には長く苦しい研究と忍耐が伴うこ とを示唆する。その例に、レオナルド・ダ・ヴィンチの名を挙げる。
「レオナルドは〈最後の晚餐〉の筆を置いたとき泣いた。なぜなら ば、彼が望むようなキリストの栄光を描ききれなかったからだ。ラ ファエロは〈キリストの変容〉を完成させた時に絶望した。なぜな らば、彼のキリストも望むべき姿をしていなかったからだ。」注27)

美術史において巨匠として位置づけられる二人の画家を作品では なく、その過程の人間性に着目して評している点は重要である。ガ ウディは晚年に断食をしてまで、神の創造する建築を発見しょうと 努めている。自身をキリス卜教芸術の作家としてダ・ヴィンチと重 ねており、ガウディ独自の視点が表出されているといえる。

次にパウ・ミラの絵画の概念をみてみよう。

「画家は詩人である。それは、パレットの筆遣いである。絵画は 調和である。彫刻は旋律である。ギリシア時代の絵画について は、高名なアペレスがいた。フラ・アンジェリコは、キリスト教 芸術を完全なものにし、そこからカタコンベが始まった。ウル ヴィーノのラファエロの師匠はペルジーノであった。ダ・ヴィ ンチは卓越しており、芸術のみではなく科学においても秀でて いた。ブオナロッティ、ラファエロ、ダ・ヴィンチは、超一流で あり、それ以外は二流である。テッツィアーノは、偉大な色彩家 で、視覚の音楽家であった。ムリーニョとパオロ・ヴェロネーゼ は、光り輝く画家である。ベラスケスは、スペイン絵画会の巨匠 である」(絵画、p.26)

ガウディがダ・ヴィンチでさえも「最後の晚餐」で、自身が納得 していないものであったと評価しているのに対し、パウ・ミラはラ ファエロやダ・ヴィンチは超一流であると評価している。両者の言 説を比べると、建築と同様に評価の不一致が確認できる。しかしな がら、イタリア・ルネッサンスの画家の列挙された名前は共通して いるものが多い。当時のバルセロナ建築大学においては「芸術論」 の講義はあったものの、その内容は「様々な様式の提示と比較、お よび古代・近代の建築や土木 ・水利施設の構造、平面計画、ならび に装飾の検討に基づく一般芸術論」注 28) であり、絵画などの芸術が 出てくるような講義はなかった。ガウディが芸術史を学べた環境は、 少なくとも大学にはなかった。そうなると学外になるが、パウ・ミ ラが精力的に展開していたアカデミーの講演会か、もしくは弟子た ちと開催していた勉強会でパウ・ミラ自身がイタリアでの留学経緯 を語りながら、自身のスケッチ（Fig.1、2）を用いて具体的に作品を 提示しながら議論していた場所に、ガウディが参加した可能性が大 きい。そこで、ガウディは芸術学の教養をパウ・ミラから学んだと 推察される。
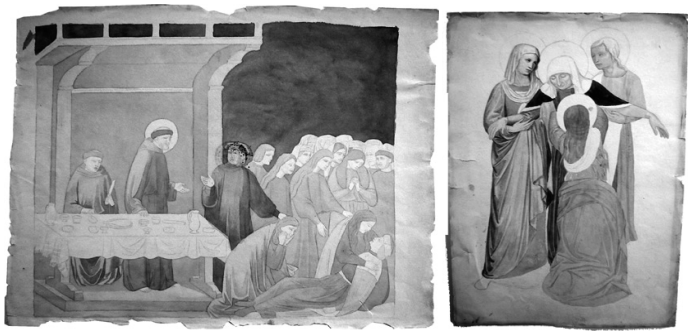

Fig.1(Left) Giotto, La muerte del Caballero de Celauo, drawn by Pau Mila. Fig.2(Right) Fra Angelico, Crucificacion, drawn by Pau Mila.

4. 装飾、創造、直観 一創作態度に関する比較考察次に装飾に関する考察を行う。ガウディの「日記装飾論」は新し 
い聖堂のヴィジョンを求めて日記調に記されているが、その鍵とな る概念は装飾である。彫刻の考察においてミケランジェロを「装飾 家」と呼んでいたが、装飾は建築と密実に関係したガウディの建築 の考え方を理解する上では、非常に重要な概念である。ゆえに、本 章ではパウ・ミラとの装飾に関する概念の比較考察を行う。

\section{1 装飾に関して}

本節では、ガウディとパウ・ミラの装飾に関して考察する。

パウ・ミラは装飾の定義を次のように述べている。

「その全てにおいて、大量の悪質よりも少量の良質が求められ る。評価されるものは、大量に制作されるものではない。装飾は 塩のようなもので、少量で効き、大量だと無意味である。もし虹 が一日中かかっているとしたら、誰も虹に見向きもしなくなる であろう。芸術やあらゆる好機に関しては、加減に注意が必要 である」(経済性、p.13)

ここで注目したいのは、「加減」についての考え方であるパウ・ミ ラは芸術における装飾の大量付加を否定している。それは、大量の 制作によってもたらされた装飾は、芸術的評価は別であることを示 唆している。

ガウディはパルテノン神殿とパリのオペラ座を『日記装飾論』で 比較考察している。パルテノン神殿の単純さと装飾の適正に対して、 オペラ座は装飾過多だと酷評している。「彼（ガルニエ）はそのファ サードを彫刻、繰形、そして様々な要素、異国趣味のそれで一杯と しなければ、自らの方法を持たぬ無力者と考えたのだらう」(原本 36 頁)。ガウディは、機械による生産、つまり色ガラスや瓦などの建材 が大量に生産される時代の必要性は理解していたが注 29)、装飾は大 量に制作される対象としてない。「装飾においては、費用だけが評価 の対象であり、費用がかかればかかるほど良しとされるのである。 しかし、全く別の考え方によれば、最も適切で、簡素であることこ そ最良である。あたかも私たちが気高いと語るように」(原本 39 頁)。 この言葉も、先ほどのオペラ座の批評と通じ、装飾は過多ではなく、 適量必要であるというガウディの建築観が分かる。前章でミケラン ジェロを装飾家として批判していたが、本節の装飾の項目と合わせ て考えると、サン・ピエトロ大聖堂の装飾が過多であることをガウ ガディは指摘しているといえる。

ガウディの『日記装飾論』は、装飾それ自体が建築の創作と梁く 結びついているものとする創作論である。その主題となる装飾の加 減を指摘することは、非常に重要である。なぜならば、ガウディも 述べているように装飾の制作は経済的な問題と結びついているから である。パウ・ミラはそれを食塩に例えて記しているが、当時のカ タルーニヤにおいて塩は決して安価なものではなかった。19 世紀力 タルーニャでは様々な様式の装飾がインディアノスらによって建設 された建築に大量に付されていく潮流があった。その潮流に警鐘を 鳴らすように、両者は装飾の適当な使用を述べている。ガウディの 建築は装飾過多のように評されることがあるが、それらは物理的な 必要性や精神的な志向をもって表現されているものである。サグラ ダ・ファミリアにおいては、「聖堂の地位を維持するためには、あま り装飾過剩になることなく、完全で威厳ある外観を与える必要があ る (原本 23 頁)」と述べている。

これらの考察を時系列的に捉えると、ガウディが若年期に記した 『日記装飾論』にパウ・ミラの装飾に関する概念とガウディの装飾
に関する考え方の一致が確認できることから、若年期に触れたパウ・ ミラの概念の影響が晚年まで一貫していることが確認できる。

\section{2 創造について}

ガウディの晚年の言葉において、創作の本質に関する言葉がある。 「創造は人間を通じて絶え間なく働きかける。しかし、人間は創造 しない。発見する。新しい作品のための支えとして自然の法則を探 求する人々は創造主と共に制作する。模倣する人々は創造主と共に は制作しない。それゆえ、創造とは起源に帰ることである」注30)。こ の考え方は『日記装飾論』には登場しない。ガウディが建築家とし て生き抜く中で思索した結果である。この言葉の中には、創造に関 する重要な定義が示されている。それは人間は創造するのではなく 発見するという考え方である。

パウ・ミラは、「感情と空想は、詩作の糧である。心がなければ、 想像力もない。芸術家は創造しない。創造心は炭では然やすもので はない」（想像、p.18）と述べている。パウ・ミラも「芸術家は創造 しない」と言う。最終行は「炭では燃えない」、しかし心を燃やすの である、という逆説的な締めくくりをしている。これは冒頭で指摘 した対比的な記述によるものである。心とはつまり、「感情と空想」 のことであり、このことは詩作に必要なものとして述べられている。 パウ・ミラにとって芸術と詩が同義であることは第一章で確認した。 それを踏まえるとこれは芸術の創作態度として記された一文である と換言できる。心を燃やすというのは、生き生きとした人間のみが 持つことが出来る創作態度であり、ガウディが述べる「人間を通じ て絶え間なく働きかける」ものは、心からの内発的な創作に対する 姿勢であるといえる。パウ・ミラが、芸術家は創造するのではなく、 心を燃やし自らの内にある空想や感情を発見しながら制作す心゙きで あるという考え方は、ガウディの創作態度と一致している。ガウデ イは常に、発見することを心がけていた。その結果として、ゴシッ ク建築の欠点を改良す心゙き方法を発見している。さらに、ガウディ はその発見するまなざしを自然の原理から発見しょうとしていた。 自然を観察する視点は、前稿のマヌエル・ミラから影響されたもの だが、マヌエル・ミラは発見するという発言はしていない。ゆえに、 創造せず自然を観察し原理を発見する創作態度は、ガウディが両者 の考え方を統合した結果生まれたものであると考えることができる。

\section{3 直観に関して 一詩的観念一}

本節ではガウディとパウ・ミラの詩的観念について考察する。 ガウディは以下のように、対象の見方について述べている。

「私はある対象の思い出を直観的なものにし、それをさらに 美しいものにつくりあげる。このことは否定することはできな い。私たちがもしその対象から心楽しい印象を受けるならば、 思い出は私たちにさらに数倍も心楽しい印象を与えるであろう。 （中略）形態の美しさは、私たちが眺めている形態に正しく反 映している観念の詩であると言えよう。それゆえ、詩的思い出 を持とうと寸れば、対象についてあらかじめ知っておく必要が ある。つまり、その表現を効果的にするために、表現したいと望 むものをよく知っておくことが必要である」(原本 66 頁)。

上記に登場する「観念の詩」について注目する。ガウディは、形 態の認識とそれに伴う直観について述べている。重要なのは、対象 の形態は物理的な捉え方ではなく、観察者の視点によって捉えられ ることを理解していた点である。次にここで、パウ・ミラが述べる 
対象の接し方に関してみてみる。

「心地よいものが芸術なのではない。また、形態でもない。芸 術は五感による精神からわき起こる喜びである。芸術はただの なされた成果物ではなく、純粋な目と耳の喜びである。」(p.11) 芸術的対象は、それに接した人間の感性の問題であることを指摘 する。両者に共通するのは、対象の印象は物理的な認識ではなく、 観察者の捉え方に依拠していることを重要視している点である。ガ ウディは、対象を直観で捉える視座を晚年へ向けて開花させていく が、パウ・ミラのとらえ方も相乗して、ガウディの総合的直観的視 点への発露を加速させたのではないかと考えられる。

さらに、ガウディはそれが詩であると述べている。パウ・ミラは、 「真理が見えた時に、詩は喚起される」注 31) と述べる。つまり、対象 を見た観察者に印象が詩的観念として形態が真理として喚起され、 その発見を「心楽しい印象」として理解するのである。知性的理解 に頼るのではなく、観察者の感性に依拠するとする見解は両者一致 している。ガウディは「自然を研究することは、私たちにある直観 力を与える」(原本 42 頁）と述べており、ガウディの「賢慮」の言 葉にも表れている通り、分析的に対象を眺めるのではなく、総合的 直観的に対象の真理を捉える必要性を述べていることから、自然の 形態研究の鍵となる概念の背景に、パウ・ミラの美学と通底する概 念を確認できたことは大きい。

\section{5. 生命観の創作態度 -パウ・ミラの美学の実践-}

本章では、ガウディがパウ・ミラから影響をうけ、それを実践し た創作方法に関して述べる。

ガウディは人体の観察の仕方においてミケランジェロよりもチェ ッリーニを評価していた注 32 。 ガウディ自身もサグラダ・ファミリ ア聖堂やグエル公園のベンチ制作の際に解剖学的視点から、造形を 決定していったことが知られている注 ${ }^{33)}$ 。その際に骨格模型などを 用いながら、ガウディは創作に没頭するが、C・プレヴォーによれ ば、ガウディは建築物の構築と彫像の理解が「同じ組織的統一を持 っているもの」と理解していて、それゆえに解剖などは、「自然主義 的手法にみられる観察の正確さというものを目的としているのでは なく、何よりも、隠されたものの直観的把握と新しい知見を目的」 注 34) としていたという。この建築観を理解するにあたり、パウ・ミ ラの美術アカデミー教員時代の資料を見る必要がある。現サン・ジ ヨルディ王立美術アカデミー注 ${ }^{35)}$ には、パウ・ミラ本人が同アカデ ミーの講義で使用した参考デッサンが保管されている。それは、多 数の人体解剖図のデッサンが存在する。パウ・ミラの絵画はラファ エロ前派注 ${ }^{36)}$ 一影響を与えたナザレ派の作風であるが、それとは別 に教壇の上では、芸術の基礎的な素養として人体構造を習得させる トレーニングを学生に課していた。「美しき人体」を描くことを目的 として解剖学的な視点にまで遡って展開されていたことがこれらの デッサンから理解される。人体に動きに合わせて動く筋肉や腱の動 きが精密に描かれており、Fig.3やFig.4に示唆されたように、腕や 腱の緊張感のある生命観が描かれている。パウ・ミラの美学の神髄 は、対象の美的真理を直観で捉えることだと換言できる。

ガウディは晚年のサグラダ・ファミリア聖堂において、彫像制作 に多くの時間を研究に費やした。まず金属製骨格で構造、表情、姿 勢について研究し、解剖学用骸骨で確認し、針金による原寸大の粗
作りが続き、次に針金で輪郭をつけた生身のモデルを連続する鏡の 前に置き写真に撮る。モデル自身を使って、彫像の粗造りが決定さ れる。距離と視点また内部と外部の位置の問題、象徴的位階による 像の大きさの検討が行われ、実際のモデルを使った石膏の鋳型をと っていたのである注 37 。「人物の表現、つまり形態の表現は骨格の動 きと共に変化するものである。その他のすべてはそれをおおうディ テールであり、その多くは遠くから見えない。…人愲格によって 動く。骨格は筋肉によって支配される梃子である。骨格を研究する ための二つのシステムがある。骨そのものの直接研究と人間の運動 の研究である。」とバルゴスに語った証言がある注 ${ }^{38)}$ 。

「芸術は美であり、美は真実の輝きである。真実なしには美は 存在しないであろう。真実を把握するには、事物を本質的に研 究しなければならない。美についていえばそれは生命であり、 運動によって人間の形態の中に現れる」注39)

ガウディが上記のように述べていることからも、パウ・ミラの解剖 学的視点での対象の発見が、ガウディの晚年の創作態度に深く影響 していることが確認される。

ガウディは「絵画は色彩で、彫刻は形態で、生きた生命を表現し、 外面の様相を通じてそれらの内面を示す。建築は生命を創造する。 それゆえ、この生命は大自然の法則に合致した法則をもたなければ ならない」注 40) と述べている。ガウディは建築に生命を与えること を目指して創作していた。パウ・ミラの概念を背景としてガウディ の創作態度を換言するならば、言語や造形で説明することができな い直観的な生命を創造するために、ガウディは自然を観察し、構造 および諸機能と形態の関係を研究し発見していた、といえよう。ガ ウディが弟子のジュアン・マタマラに同書を渡したとき、「普遍的な 原理が記してる」と言葉を添えていたが、その原理はまさに上記の ことであると考えられる。その実践として、サグラダ・ファミリア 聖堂での彫像制作過程にそれを確認することができた。

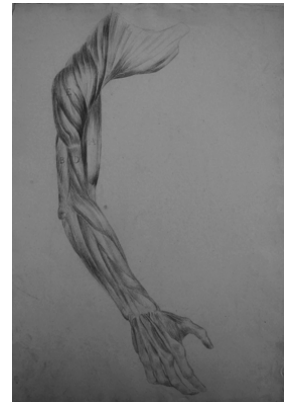

Fig.3 Pau Mila Sketch 1

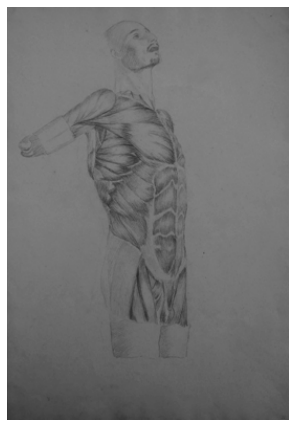

Fig.4 Pau Mila Sketch 2

\section{結論}

以上により、ガウディの『日記装飾論』ならびに晚年の言葉を、 パウの美学書『直観の美学』を用いながら、比較考察することを通 して、ガウディの建築観にはパウ・ミラの諸概念の影響があること を明らかにできたと考えている。

具体的には以下に挙げる通りである。

第一に、本研究の目的と構成に関して述べた。

第二に、芸術について考察した。パウ・ミラは芸術を五大芸術と して視覚芸術までを含めて芸術としていたが、ガウディは視覚芸術 
を主たる芸術として捉えていたことが明らかになった。また、前稿 で考察したマヌエル・ミラは彫刻や絵画の理論的な説明に終始して いたが、パウ・ミラのそれは具体的な巨匠の名前が列挙されており、 その登場する芸術家がガウディの『日記装飾論』や晚年の言葉に多 分に散見されることを確認しながら、その評価は不一致であったこ とも確認した。しかしながら、絵画の考察で、当時の建築大学での 芸術史講義における芸術学に関する内容の久如、パウ・ミラの市内 での教育活動の史実、列挙するイタリア・ルネッサンスの巨匠の一 致などからガウディはパウ・ミラから芸術史の教養を学んだと考え ることができる。さらに、両者がギリシアの建築や彫刻を高く評価 していた点も重要である。ガウディが活躍したカタルーニャ・ムダ ルニズマ運動は、ドメネク・イ・ムンタネーやプッチ・イ・カダフ アルクらが、スペインのムデハル建築を目指寸理想として設計して いた。それに対して、ガウディはサグラダ・ファミリアを「地中海 ゴシック様式の古代ギリシア的聖堂であり、民族の解放を表すもの である」（DS.p.19）と称しており、聖堂を建造するために、真の聖 堂のあり方を模索してたガウディはゴシック大聖堂を批判的に考察 し、その先にギリシア建築を真の芸術として見通していた。そのた め、ゴシックのフライング・バットレスを批判し、構造的合理性を 追求した結果としてカテナリー曲線の構造体へと到達している。真 の美として調和されたギリシア建築を頂点に捉える視点は、同時代 の建築家の間では異彩なものであるが、ガウディとパウ・ミラの両 者に共通した点であることから、パウ・ミラの存在はガウディにと って重要であったといえる。

第三に、装飾について考察した。ガウディの『日記装飾論』は、 装飾それ自体が建築の創作と深く結びついているものとする創作論 である。その両者は装飾の問題を経済性と結びつけて論じている共 通点を確認し、両者が当時の装飾過剩なデザインに敏感に反応して いたことが確認された。適量が芸術美につながるという姿勢も確認 できた。次に、創作に関して考察した。両者が「芸術家は創造しな い」という発言を残していることを端緒として、内発的な心におけ る想像が、創作の発露になるとしたパウ・ミラの考え方がガウディ に影響を与えたであろうことを指摘した。さらに、詩的観念につい て考察した。ガウディは形態の美しい「観念の詩」であるといい、 それには、パウ・ミラの「真理」の項目に記された「真理が見えた 時に、詩は喚起される」が同じ意味をもつこと突き止め、ガウディ の述べる直観ならびに詩的観念の意義ならびにその背景をパウ・ミ ラの概念を参照して明らかにできたと考えている。

第五に生命観の創作態度としてパウ・ミラの解剖学的視点から自 然の対象から真理を発見する創作態度に関する考察を行った。サグ ラダ・ファミリア聖堂で行われていた解剖学的手法は形態の真理を 発見するためであり、第四章で論述した直観を実践した行為として 確認することができた。

以上の考察を通じて、これまでガウディ研究では、彼の創作方 法は自然の構造的な研究や、実験的な発見から創造するという創作 方法に主眼が置かれて論じられてきたが、本研究はそれらとは峻別 され、ガウディは自然の構造や形態を観察し、そこにある生命を研 究することを通じて、詩的かつ直観的にその真理を発見する創作態 度を実践していたことを明らかにした。さらに、その背景としてパ ウ・ミラの美学の概念の存在を表出できたことはガウディ研究にお
ける新たな発見である。

前稿と合わせてガウディとパウ・ミラの関係について考察してき た。J・ラフルスが記した『ガウディ』（1929）の中にある「ミラ・ イ・フンタナルスの弟子」という一文を端緒として、ガウディの建 築観の背景には、ミラ・イ・フンタナルス兄弟の美学の諸概念の影 響があることを明らかにできたと考えている。今後は、ガウディと 同世代の建築家、宗教者、詩人らへとその考察の対象を広げていき たい。ガウディが活躍した前近代のヨーロッパは、学派や思想が国 を超えて様々な学問を内包した建築論が誕生する黎明期であるとい える。ガウディを端緒として、建築論の近代性に関して明示される ものがあると見通している。

\section{謝辞}

本研究は、今井兼次先生によって始められ、ドミニコ会神父故渡 辺吉徳氏の助力によって早稲田大学今井研究室、池原研究室、なら びに入江研究室において長年の間続けられてきたガウディ研究の蓄 積の上に成立したものである。

本研究は科学研究費補助金（若手 B : 24760525）を基礎として、 文部科学省科学技術人材育成費補助金テニュアトラック普及・定着 事業、早稲田大学特定課題 B（2018B-128）の助成を受けたもので ある。また 2018 年度日本建築学会大会梗概に加筆したものである。

\section{注}

注 1) カタルーニャ人の人名表記に関して、文献によってはスペイン語表記の ものもあるが、混乱をさけるためにカタルーニャ語表記に統一して翻訳し た。

注 2) 拙稿、「建築家アントニ・ガウディと美学者マヌエル・ミラの諸思想の 関係について」、日本建築学会計画系論文集 77(672), 453-461、2012.02 注 3) 建築への考え方を本研究では建築観としてよぶ。

注 4) 拙稿、「建築家アントニ・ガウディと美学者ミラ・イ・フンタナルス兄 弟の関係について」日本建築学会計画系論文集 75(651), 1287-1292, 2010.05

注 5) Gaudí, Antoni, EL Manuscrit de Reus, 1873-79。(『ガウディの言葉』、 入江正之編訳、東京、彰国社、1993) 引用ページを（原本_頁）の形で示す。

注 6) Pablo Milà y Fontanals, Estética infantil, Barcelona, Tipografía Moderna, 1904. 引用ページを（p._）の形で示す。注 5 番との混同を避け るためである。

注 7) Matamala, Juan, Mi initerario con el arquitecto, Barcelona, Claret, 1999, p.146 彫刻家リ $コ$ レス・マタマラとの会話でガウディは以下のよう に述べる。「『この本を息子さんに手渡したらどうか。そして、読ませてみ なさい。これは宝物です。Pablo Milà y Fontanals (1810-1883)によって書 かれたものです。このタイトルは Estética infantil です。序文に書いてあ るように、出版することを強く頼み込んだ友人達が編纂したものす。大人 のためでもあり、また入門書でもあります。もし君の息子がこれを読んで、 喜んで記憶に留め上うとしたら、正しい道を進んでいることでしょう。そ の時は、この本を彼に差しあげます。もし彼が興味を示さなかったら、そ の時は返して下さい。』私の父は私に暗記するように言った。内容は、韻 が踏んであるので覚えやすかった。『この内容を理解し、もし気に入った なら、アントニオさんに感謝せよ。』と父は私に言った。数日後、私は賃金 台帳の作成のためアトリエに行った。そこではガウディと話すチャンスが よくあり、彫刻のアトリエを訪れるよりも良かったので、この本のことを とても感謝した。すると、ガウディは『この《美学者》は時代の些細な先入 観を除いて、芸術の普遍的な原理が記されており、とても学識豊かな書物 である』と私に言った。」

注 8) Johann Friedrich Overbeck (1789 - 1869)

注 9)マリア・フルトゥニー。Marià Fortuny i Marsal（1838-1874）。カタ ルーニャの画家。パウ・ミラに師事しアルハンブラ宮殿の絵画や大作「テ トゥアンの戦い」（カタルーニャ州立美術館蔵）などで有名である。

注 10) Elias de Molins , Antonio, Diccionario Biográfico y Bibliográfico de 
escritores y artistas catalanes del siglo XIX, Barcelona, 1889, Tomo II, p.184

\section{注 11) D.Celestiono Verdageur}

注 12) Remirez y Carlos

注 13) El Vendrellense

注 14) 初版本は絶版となっており、現在入手できているものは、1904 年度版 のものである。ガウディが実際に手にしていたものがどの版のものかは不 明である。しかし、内容は当初のものと変わらないことをサン・ジョルデ イ王立アカデミーで確認しており、1904 年度版を用いて考察している。

注 15) Sumario pintoresco español, Madrid, p.335「宗教的絵画は、我々にと って、自然と固有の精神性、様式と形式を備えていなければならない。力 トリック信仰者に糧を与える、気高く純粋な感情の精神を目覚めさせる道 徳的理想を描かなければならない。従って、絵画が視覚を満足させること だけを目的とするなら、それは単なる知的作業である。それ以外には、宗 教絵画の要素は（一般的な絵画についても同様だが）輝かしい派手な色彩 や、光と影の対比、丹念で学識豊かなタッチなどが、あげられるだろう。 しかしながら、心の興奮を摇さぶる生命の感覚の形を感じるとき、また芸 術家と観察者において精神的好感を伝達手段する役に立つとき、真の芸術 の創造に感嘆するのである。しかしながら、これが宗教的絵画を定義して いるかどうかは、定かではない。もし、地球上の存在として隆起せず、思 索や礼拝への慈悲に埋没しなければ、人の心を動かしたり、絵画的意味を 十分に満足することはない。感性、愛情、神秘的なイデアは、我々の理解 では、キリスト教絵画における聖梖にて保管されてしまっている三つであ る。そして、この三点による三角形の重心は、社会的背景や文化的背景に 依存する。

注 16) Puig Boada, Isidro, El Temple de la Sagrada Familia, Barcelona, Barcino, 1929, p.170 (『ガウディの言葉』、入江正之編訳、東京、彰国社、 1993、p.118)

注 17) Bassegoda Nonell. Juan, Las Conversaciones de Gaudí con Juan

Bergós, "Hogar y Arquitectura" No.112, Num.22, Arquitectura sin arqueología

注 18)ガウディは、詩作に関してもいくつか言説を残している。ガウディは生 涯を通して幾人かの詩人と友好な関係を築いていた。ジャシン・バルダゲ — (Jacint Verdaguer i Santaló Folgueroles, 1845-1902) や、ジョアン・ マラガイ (Joan Maragall i Gorina, 1860-1911) らがそうである。バルダ ゲーは、カタルーニャの国民的詩歌コンテスト〈花の宴〉の第一回（1878 年) において、金賞を受賞した。グエル家の庇護の元に大成した詩人であ り、グエル伯爵を通じて知り合った。L'Atlandida (Verdaguer, Jacint, L’Atlandida, Barcelona, 1878）を発表し、当時のカタルーニャのみならず、 フランスにおいても高い評価を得た高名な詩人として活躍した。この二人 は、「協同でしなかったが、深い共感を得た意思疎通」（Torrent, Richard, Gaudi y Verdaguer, Barcelona, Museu d'Història de Barcelona · Institut de Cultura, ajuntamet de Barcelona, 2002, p.56) があった。ガウディは 晚年にバルダゲーについてこう語っている。「実りある唯一の道は繰り返 しの道である。ベートーベンにおいては、10 年前に用いられた繰り返しが みられる。バッ八においても同様だ。カタルーニャの詩人ジャシン・バル ダゲーは自らの詩を推敲する一方で、繰り返し反復する」（Bassegoda, op.cit.12, Num.207. (『ガウディの言葉』、p.152) ) と述べている。ベル ダゲーをモーツァルトやバッハと同じレベルの芸術家として位置づけてお り、先ほど述べた芸術家の苦悩に関する限り、苦痛の努力を続けた偉大な 先達の一人として理解していたことが明らかである。しかし、このような カタルーニャを代表する詩人に対しても、パウ・ミラは彫刻家の評価と同 じように、古代ギリシア・ローマの芸術家とイタリア・ルネッサンスの芸 術家のみを賞賛する。「詩作は我々の精神を感情と、考えと、調和でもっ て満たしてくれる。ギリシア時代には悲劇、風刺、喜劇が創られた。ギリ シア時代の偉大な神と人々は、ホメロスの歌を讃えた。ウェルギリウス、 ホラティウス、ルカらは、ローマ時代の Parnas の光である。トルバドゥー ルからプロヴェンサ地方にて、我々の詩作が始まった。ダンテは詩人であ り、神学者であり、哲学者であった。セルバンテスとカルデロンは、カス ティージャの誇りである。ラファエロ、ダンテ、モーツァルトは、芸術に おける天空の星座である」（詩作、p.27）。セルバンテスはスペイン文学を 切り開いた作家である。ガウディは辛辣に中央カスティージャを批判して いたが、その中で考えるとセルバンテスを賞賛することは極めて希有であ る（（Bassegoda, op.cit.12, Num.123.））。しかし、それはセルバンテス の芸術としての詩作の評価ではなく、彼がカタルーニャを賛美した態度を ガウディは評価していたようである。「セルバンテスは、地中海からの帰
路についた〈ドン・キホーテ〉を描いている。（中略）バルセロナやカタル 一ニヤ語への賞賛、さらにカタルーニャの海賊までも含めた賞賛は見事で ある」（Bassegoda, op.cit.12, Num.38.）。

注 19) Oriol, Bohgas, Reseña y Catalogo de la arquitectura modernista, Lumen, 1968 (『モデルニスモ建築』、稲川直樹訳、みすず書房、2011 年、 p.99)

注 20) Bassegoda, op.cit.17, Num.60

注 21) Bassegoda, op.cit.17, Num.09

注 22) Bassegoda, op.cit.17, Num.60

注 23)フィディアス。Pheidias。前 490 - 前 430、前 5 世紀に活躍のアテネの 彫刻家。アクロポリスならびに、パルテノン神殿の再建を担当した。

注 24) Matamala Flotats, Juan, La Naturaleza en la obra de Gaudí, "V Certamen:Centro de Lectura", Reus, 1952, Tomo I, p.590（『建築家ガウ

ディ全語録』、鳥居徳敏、中央公論美術出版、東京、2007 年、p.539)

注 25) Gaudi, op.cit.4, p.26（『ガウディの言葉』、入江正之編訳、東京、彰 国社、1993、p.72)

注 26) Bassegoda, op.cit.17, Num.209（『ガウディの言葉』、p.115）

注 27) Bassegoda, op.cit.17, Num.18.

注 28) 鳥居徳敏、『建築家ガウディ全語録』、中央公論美術出版、東京、2007 年、p. 45

注 29) Gaudi, op.cit.4, p.20（『ガウディの言葉』、p.66）「多くのエレメン 卜を入手するために様々な手段が標準化されるのを調べてみよう。知られ ているように、数年前からこの方面では役割を果たしてきた産業がいくつ かある。誰もが色ガラス産業を予測できたし、鉄の鋳造、あるいは、大理 石の切出し産業なども長い年月を要しなかった。私たちは、同じくすでに 特別な機械を必要とする機械生産の瓦工場をいくつか持っている。」

Gaudi, op.cit.4, p.19（『ガウディの言葉』、p.64）「今日、全てにわたつ て、手間賃があり、材料費が下がる傾向にある。今世紀［19世紀］の初頭 から全ての産業分野において、一日の手間賃が 2 倍、3 倍、4 倍となる傾向 にあることを誰もが知っている。もちろん、これはわずかの時間で大量に 制作する機械類の導入による結果である。」

注 30) Bassegoda, op.cit.17, Num.16.（『ガウディの言葉』、p.120) 注 31) Mila y Fontanals, Pablo, op.cit.6, p.14「真理 : 石灰のような芸術と、 誉れ高き人間は、常に真理を語る。それは、物質的真実ではなく、美と理 想の真理である。その真理が観えたとき、詩は喚起される。良質な芸術は、 美や真理なしではありえない。観た芸術、思考された芸術、そしてその他 に、夢見た芸術がある。」

注 32) Martinell i Brunet, Cèsar, Conversaciones con Gaudí, Ediciones Punto Fijo, Barcelona, 1969, p.43.「ベンヴェヌート・チェッリー二は、こ の解剖学を徹底して研究した芸術家であり、ギリシア彫像の修復の委託を されたが、その結果はどの部分が修復されたのか分からない程であった。 ミケランジェロは筋肉組織を好んで研究した。この意味では、ベンヴェヌ 一ト・チェッリーニに劣る。（鳥居徳敏、『建築家ガウディ全語録』、中央 公論美術出版、東京、2007 年 M.GSF-068.03、p.419) ) 」

注 33) Matamala, Juan, Mi initerario con el arquitecto, Barcelona, Claret, 1999、pp.103-104。「ガウディは先人が鋳造によって製作したという確信 を持っていたので、『古い彫刻のいくつかは解剖学的な精密さと個々に示 された個性が表現されていて、とてもシンプルだったのにも関わらず本物 のように思える』とガウディは言った。（中略）彼はこう言った『鋳造は裏 切らない。それらも同じように造られたのだろう。』ガウディはこう言っ て、独創的で革新的なのにも関わらず古い彫刻に夢中になった。」

注 34) Descharnes, Robert / Prévost, Clovis, La Vision Artistique et religieuse de Gaudí, Lausanne, 1969, p. 106(『ガウディ 芸術的・宗教的 ヴィジョン』、東京、鹿島出版会、入江正之他訳、1993、p.118)

注 35) Reial Acadèmia Catalana de Belles Arts de Sant Jordi

注 36) ラファエロ前派。Pre-Rapaheliate Brother。1 1848 年、ジョン・エヴァ レット・ミレー(Sir John Everett Millais 1829-1896) 、ウィリアム・ホル マン・ハント(William Holman Hunt 1827-1896)、ダンテ・ゲイブリエル • ロセッティ(Dante Gabriel Rossetti 1828-1882)らによって「ラファエル前 派兄弟団」(Pre-Raphaelite Brotherhood)がイギリスで結成された。象徴主 義の先駆とされるラファエル前派は、ラファエロ以後の西洋絵画を退廃と 見なして、中世や初期ルネサンスの芸術を範とした。彼らはラファエロ以 前のイタリアやフランドルの芸術が持つような精神性を重視し、回帰を提 唱していた。それは、彼らが当時のロイヤル・アカデミー・オブ・アーツ (王立美術学校) での教育を批判することも意味した。(『ラファエル前派』 ローランス デ・カール 著、高階秀爾監修、東京、創元社、2001) 
注 37 ) 入江正之著、『アントニ・ガウディ論』東京、早稲田大学出版部、 1997. p. 316

注 38) Bassegoda, op.cit.17, Num.223,

注 39) Bassegoda, op.cit.17, Num.34,

注 40) Bassegoda, op.cit.17, Num.160,

\section{参考文献}

1) Takeshi Yamamura and Masayuki Irie:Relationship between Antoni Gaudí and Milà y Fontanals, Journal of Architecture and Planning (Transactions of AIJ), Vol. 75, No. 651, pp.1287-1292, 2010.5 (in Japanese)

山村健, 入江正之:建築家アントニ・ガウディと美学者ミラ・イ・フンタナル ス兄弟の関係について, 日本建築学会計画系論文集,Vol. 75, No. 651, pp.1287-1292, 2010.05

2)Takeshi Yamamura and Masayuki Irie:Comparison between architectural theory of Antoní Gaudí and Aesthetic theory of Manuel Milà, Journal of Architecture and Planning (Transactions of AIJ), Vol. 77, No. 672, pp.453-461, 2012.2 (in Japanese)

山村健, 入江正之,建築家アントニ・ガウディと美学者マヌエル・ミラの諸思 想の関係について,日本建築学会計画系論文集, Vol. 77, No. 672, pp.453461, 2012.2

3)Pablo Milà y Fontanals:Estética infantil, Barcelona, Tipografía Moderna, 1904

4) Matamala, Juan:Mi initerario con el arquitecto, Barcelona, Claret, 1999 5)Elias de Molins , Antonio:Diccionario Biográfico y Bibliográfico de escritores y artistas catalanes del siglo XIX, Barcelona, 1889

6)Puig Boada, Isidro:El Temple de la Sagrada Familia, Barcelona, Barcino,
1929

7)Masayuki Irie:Words of Gaudi, Shokokusya, Tokyo,1993

入江正之編訳,ガウディの言葉,彰国社,1993

8) Bassegoda Nonell. Juan:Las Conversaciones de Gaudí con Juan Bergós, "Hogar y Arquitectura" No.112

9)Tokutoshi Torii:Gaudi, sus escritos y palabras completos, Chuo-Koron Bijutsu Shuppan, 2007

鳥居徳敏,建築家ガウディ全語録,中央公論美術出版,2007

10)Martinell i Brunet, Cèsar:Conversaciones con Gaudí, Ediciones Punto Fijo, Barcelona, 1969

11)Descharnes, Robert / Prévost, Clovis:La Vision Artistique et religieuse de Gaudí, Lausanne, 1969

12)Laurence Des Cars, Les Préraphaélites:Un modernisme à l'anglaise, Gallimard , 1999

13)Torrent, Richard:Gaudi y Verdaguer, Barcelona, Museu d'Història de Barcelona · Institut de Cultura, ajuntamet de Barcelona, 2002

14)Oriol, Bohgas:Reseña y Catalogo de la arquitectura modernista, Lumen, 1968

15)Masayuki Irie:Theory of Antoni Gaudi, Waseda Univ.Press, 1997

入江正之,アントニ・ガウディ論,早稲田大学出版部, 1997

図版出典

Fig.1,2,3,4 La Reial Acadèmia Catalana de Belles Arts de Sant Jordi 
How did architect Antoni Gaudi get the idea from anatomical study to make sculptures of Sagrada Familia church? We know that he studied so hard to find out the ideal form for each sculptures, however we don't know where his idea came from.

This paper discuss that A.Gaudi was influenced by an aesthetician Pau Mila y Fontanals. Pau Mila was a professor of aesthetic in Barcelona at that time. He is a brother of aesthetician Manuel Mila y Fotanals on whom the author did research in the previous paper. Pau Mila's original drawing which was used for his classes are archived in La Reial Acadèmia Catalana de Belles Arts de Sant Jordi. These drawings emerge the philosophy of this aesthetician indicating that the anatomical study was essential to find the best form in nature beauty. On the other hand, he wrote one book about his aesthetic theory" Estetica Infantil" which explains his ideas. Juan Matamala, the one of the disciple of A.Gaudi, wrote that it was the Gaudi's favorite book. Thus it is reasonable to compare the ideas of the aesthetic of Pau Mila y Fontanals and the architectural theory of Antoni Gaudi in this paper.

In this paper, the author compares on the ideas of Art, Ornamentation, Creation, Poem, and Architecture.

On Art, A.Gaudi was influenced by a lot of artistic knowledge from Pau Mila y Fontanals. Especially in Italian Renaissance Art. And also the anatomical study for Sagrada Familia's sculpture was based on the idea of the aesthetic method of Pau Mila y Fontanals. The Origen of the creation process for the sculptures for Sagrada Familia is as same as that of ideal the painting of Pau Mila y Fontanals. On the ornamentation, A.Gaudi said that the ornamentation by itself can be an architecture. Therefore the amount is not an important but the content is more important. Pau Mila y Fontanals wrote the same theory. On the creation, A.Gaudi said that the artists don't create but discover. The principal of the aesthetic of Pau Mila included the same idea of A.Gaudi that tried to discover some ideas from nature.

On the Poem, the background of the words of A.Gaudi which express on the truth of beauty came from Pau Mila's Philosophy. On the Architecture, There was a few influence form Pau Mia y Fontanals theory in the theory of A.Gaudi. The author defines the influence on Architecture from Manuel Mila y Fontanals was much stronger than that of Pau Mila y Fontanals. Therefore the author find that Manuel Mila y Fontanals had several influences on A.Gaudi's aesthetic idea for architectural design.

Through previous three papers, these studies was started from the words of J.F.Rafols' book saying that A.Gaudi was discipline of the brother Mila y Fontanals, and the author found that there were deep aesthetic influence and background in the theory of A.Gaudi's architectural theory. 